\title{
Housing Tenure Choice and Housing Affordability in Nigeria: A Comparative Analysis of Owners and Renters of Organized Private Sector Housing
}

\author{
Samson Akinbamide Omobayo Adegoke ${ }^{1}$, Tunde Agbola ${ }^{2}$ \\ ${ }^{1}$ Doctor, Department of Estate Management and Valuation, Osun State College Of Technology, Esa-Oke, Osun State, \\ Nigeria \\ ${ }^{2}$ Professor, Department Of Urban And Regional Planning, University Of Ibadan, Oyo State, Nigeria \\ Correspondence: Samson Akinbamide Omobayo Adegoke, Department of Estate Management and Valuation, Osun State \\ College Of Technology, Esa-Oke, Osun State, Nigeria.
}

Received: May 26, 2020

doi:10.11114/ijsss.v8i4.4905
Accepted: June 18, $2020 \quad$ Available online: June 23, 2020

URL: https://doi.org/10.11114/ijsss.v8i4.4905

\begin{abstract}
Housing tenure choice is one key decision that a household must make. This decision has been established to have direct implications for household housing affordability. This research assessed and compared the housing affordability of owners and renters of organized Private Sector Housing delivery in Nigeria. Data were collected from eleven (11) states and the Federal Capital Territory across the six (6) geo-political zones of Nigeria. A cross-sectional survey design was adopted with multi-stage sampling technique employed to select estates residents for interview. Structured questionnaire were administered on $10 \%(1,950)$ heads of households randomly selected from all the occupied houses. The study revealed that $48 \%$ of the residents were owners and 52\% renters. It was discovered that more owners than renters are under severe housing affordability stress/burden. While $29 \%$ of owners enjoy "normal housing affordability" (housing expenditure of $1 \%-30 \%), 41 \%$ of renters enjoyed such. Also, while $36 \%$ of owners enjoyed "tolerable housing affordability" (30.1\% - 50\% housing expenditure), $41 \%$ of the renters fall within that range. Furthermore, while $35 \%$ of owners are theoretically under severe housing affordability stress/burden (with $>50 \%$ housing expenditure), only $18 \%$ of the renters are. The study confirmed that renters enjoyed better housing affordability than the owners. Major policy implications include the need for housing policy and delivery in Nigeria to recognize and facilitate rental housing while steps should be taken to relieve the burden of home ownership by working on mortgage penetration, cost of building materials and other incidental expenses of ownership so as to enhance housing affordability of Nigerians.
\end{abstract}

Keywords: housing tenure choice, theory of consumer choice, owners and renters, normal housing affordability, tolerable housing affordability, housing affordability stress/burden

\section{Introduction}

One of the key decisions made by any household is the choice between owning and renting their home (Dagmar et al; 2014). According to Arimah (1997), a key factor in tenure choice decision is the relative price of home-owning to that of renting. Although some authors viewed tenure choice decision as an independent decision, a more common opinion is that it is only one part of all other decisions households have to make in relation to consumption and investment (Turnner and O'Neal, 1986). Housing affordability is intended to guarantee the housing provided is moderate and affordable by every income earner group whether low-pay, middle pay and high paid group. Stone, (2006) has characterized that housing affordability is a connection between housing and people. Housing affordability is one of the key factors that can depict the financial strength and advancement of a nation. Therefore, what may appear as a simple binary choice, between renting and owning might as well reflect a tighter constraints on other items in the consumption basket of the household with serious implications for the overall welfare of the household (Jameson, et al, 2004); particularly, housing affordability.

Housing tenure decision reflects a complex and inter-related set of factors. Range of variables influencing tenure choice is broad and includes household status and financial circumstances, as well as preference (Jameson et al, 2004). The neo-classical theory of consumer choice - "housing and other goods theory" is particularly relevant here as it 
established that any decision to consume housing is a "trade-off between spending on housing and spending on other items in the consumption basket." Therefore, if housing (owning or renting) consumes too high a proportion of household income, a household will be forced to consume less of other goods of necessity (non-housing goods). Since housing affordability, based on residual income approach, is a measure of the degree of incursion of housing expenditure on the residual of income for non-housing expenditure, tenure choice decision will always affect housing affordability. More importantly, since housing cannot be consumed in part, a certain minimum must be consumed by a household at any given time. Furthermore, since housing usually take first priority, and whatever is left is then available for non-housing goods of necessity, housing tenure choice decision therefore have direct effect on housing affordability. This is the rationale for this analysis of housing tenure choice and housing affordability of home-owners and renters of organized private sector housing delivery in Nigeria. This paper therefore compares the housing affordability of owners and renters of organized private sector housing to know which of the two groups enjoys better housing affordability.

This paper is divided into six (6) parts. The first part is the introduction, while the second part takes a cursory look at housing policy and delivery in Nigeria. The third section is a discussion of the nexus between housing tenure choice and housing affordability. The fourth part of this paper is the research setting and methodology while the fifth section presents data analysis and results. The last section is devoted to the discussion of findings, policy implications and conclusion.

\section{Housing Policies and Delivery in Nigeria}

Housing policies and delivery in Nigeria until recently, have been erratic and uncoordinated, responding largely spontaneously to unfolding issues. Although housing policy and delivery in the country has been characterized by reactions to momentary problems, without much effort to look beyond the immediate problems, it nonetheless varied with different eras and governments.

\subsection{The Colonial and Post-Independence Era (1900-1966)}

The colonial era witness no policy for housing in the real sense of it, but had a firm commitment to housing provision for the expatriates and few top African civil servants. The post-independence era, which coincided with the first civilian administration between 1960 to 1966 witnessed a renewed emphasis on direct construction of houses for the top civil servants in the Government Reservation Areas across the country; an extension of the colonial housing legacy. During this period, the first of the five (5) yearly National Development Plan (1962 - 1968) was introduced to the country "as the vehicle for economic growth" (FGN, 1991). In the plan, housing was subsumed under Town and Country Planning, and funds allocated for this sector was very small (Onibokun, 1998). This period saw the birth of the Association of Housing Corporations of Nigeria, which still remains a vital institutional anchor for housing delivery in the country till today. Although the era sustained the elitist housing delivery legacy of the colonial era, the emergence of regional housing corporations that were to serve as effective vehicle for housing delivery in the country was a green light in the tunnel; despite the fact that they did not have much overall impact due to lack of funds and technical personnel" (Onibokun, 1985).

\subsection{The First Military Administration of 1966-1978}

This era coincided with both the three year civil war and post-civil war reconstruction activities. This period also witnessed "unprecedented growth in urban population and in the physical expansion of the cities of Lagos, Ibadan, Kano, Port-Harcourt, Enugu Benin-City and Kaduna" (Agbola et al, 2016). This period saw many concerted efforts of government to address housing challenges in the country. Prominent among these were the formulation of Second and Third National Development Plans to cover 1970 to 1974 and 1975 to 1980 respectively. During the period, the National Council on Housing was established. Also, as part of reconstruction efforts, "a target of 60,000 housing units was set to solve the urban housing problem and to rehabilitate war damaged dwellings; which eventually led to the establishment of Federal Housing Authority in 1973 to coordinate a nationwide (housing) programme" (Agbola et al, 2016). As part of major efforts to confront the growing housing problems, the Third National Development Plan (1975 1980) gave birth to the Federal Mortgage Bank of Nigeria. During the same period, Rent Control Law was passed in response to the outcry of tenants in the urban centres. Similarly, Land Use Act was passed in 1978 to easy the problem of access to land for housing. Also, Employers' Housing Liability Edict, which made it mandatory for all employers with at least five hundred (500) workers to provide housing estate for them, was promulgated. All these were to boost housing supply and address acute shortage.

It was not surprising that all these were initiated during this period, because it was in this third National Development Plan that government came out boldly, when it was stated that "government now accept it as part of its social responsibilities to participate actively in the provision of housing for all income groups and will therefore intervene on a large scale in this sector during the plan period." According to (FGN, 1975), "the aim of this intervention is to achieve significant increase in supply and bring relief especially to the low income group who are the most affected by the 
current acute shortage." Unfortunately, much success was not achieved, due to shortage of funds, shortage of trained technical personnel as well as lack of both the will and the zeal needed to implement the housing delivery programmes.

\subsection{The Second Civilian Administration (1979-1983)}

This administration witnessed the most ambitious housing delivery plan in the history of the nation. The 1979 Federal Constitution laid the foundation for the impetus in the housing sector during this period. It states that "the welfare of the people shall be the primary purpose of government. That the material resources of the community are harnessed and distributed as best as possible to serve the common good... that suitable and adequate shelter are provided for all citizens" (FGN, 1979). Expectedly and in line with the constitutional provision, all political parties accorded very high priority to housing in their manifestoes. Subsequently, both the Federal and State Governments, despite differences in party affiliations, committed themselves to a programme of massive investments in housing. This led to an elaborate National Housing Programme in 1980 which was predicated on the "concept of affordability and citizen participation" (FGN, 1991); with the low and medium income groups as the target and "core housing concept" as a major strategic tool of the programme.

The climax of the euphoria for housing delivery in Nigeria during this period was the formulation of the first National Housing Policy in 1981. Prominent among the objectives of this policy was "to encourage every household to own its own house, by providing more credits and to ensure that the provision of housing units is based on realistic standards which the prospective home owners can afford" (FGN, 1991). On the whole, little was achieved in term of actual housing delivery. The politics of housing overshadowed the provision of housing; and as rightly captured by FGN, (1991), less than 15 percent of the planned dwelling units during the period were actually completed (delivered).

\subsection{The Second Military Administration (1984-1992)}

This era witnessed the emergence of the Fourth National Development Plan and the Second National Housing Policy. The Structural Adjustment Programme (SAP), a programme of stringent economic and financial restraints on public expenditure, was introduced. This period also coincided with the time the World Bank was canvassing "a number of important new policy directions for both the Bank and its borrowers" (World Bank, 1993). The central theme of the new policy directions is to

\section{"enable housing market to work more efficiently with governments advised to abandon their earlier role as producers of housing and adopt an enabling role of managing the housing sector as a whole."}

In line with this paradigm shift, government thus sees housing as an economic sector as against the old perception of housing as an area of social responsibility. Sequel to the paradigm shift, the National Housing Policy trust to enhance effective housing delivery was hinged on two (2) policy objectives, which are:

(i) Public sector intervention: The encouragement and promotion of all tiers of government in housing delivery. Also, all public institutions that are directly involved in housing delivery are to be strengthened so as to be more responsive to demand and emphasis housing investments which satisfy basic needs on the basis of affordability; and

(ii) The encouragement of vigorous participation of private sector in housing development.

This period witnessed the commercialization of housing delivery in Nigeria. This led to the strengthening of the Federal Mortgage Bank as apex housing bank in Nigeria and subsequent establishment of Primary Mortgage Institutions (PMIs) and National Housing Fund (NHF) in 1989 and 1992 respectively.

According to FGN (2004) The National Housing Fund is to mobilize loanable funds from workers, which will be disbursed through the newly created Primary Mortgage Institutions (PMIs) with the Federal Mortgage Bank of Nigeria playing the role of apex/supervisory body. Urban Development Bank was also created through decree No. 51 of 1992 to finance urban infrastructure that will in turn facilitate individual and private sector housing development. All the above notwithstanding, Federal Government was still involved in direct housing construction through Federal Ministry of Works and Housing and Federal Housing Authority (FHA); at state capitals and the Federal Capital Territory. They also embarked on site and services scheme to "facilitate house ownership and orderly urban and rural development for all income groups with special emphasis on the low income group in major cities in the country" (FGN, 1991).

This period was the beginning of commercialization of housing delivery and the recognition and encouragement of private sector participation in housing delivery in Nigeria. However, the failure to review the Land Use Decree of 1978 and other vital institutions as contained in the National Housing Policy of 1991 greatly hindered the overall success of the policy to enhance housing delivery at the scale envisaged when it was formulated. 


\subsection{The Third Civilian Administration (1999 to Date)}

The new democratic dispensation kicked off with unprecedented zeal for housing delivery. Thus from the onset, concern has been expressed at various fora about the dire housing situation for virtually all segments of the Nigerian Population, except perhaps, the very rich (Mabogunje, 2004). The cumulative deficit in housing delivery, apparently, a reminiscent of failure of past governments efforts in addressing housing problems has resulted in a national housing crisis, which heightened affordability challenge. Therefore, determined to confront the ever increasing housing crisis, the new civilian administration set out to correct the lapses of the 1991 National Housing Policy. This led to the formulation of the Third National Housing Policy in 2002. The 2002 National Housing Policy marked a radical departure from the past and a pragmatic approach to the future. The main features of the policy that distinguishes it from all other housing policies in Nigeria was succinctly captured by Mabogunje (2004) as:

"The main thrust of the new policy is to seek vigorously to make an increasing majority of
Nigerians home-owners on the basis of mortgage finance. This entails the involvement of a
large number of Private Sector Real Estate Developers and State Housing Corporations in the
development of estates with houses for sale at affordable prices to low and middle income
groups in the country; promoting the growth of many small and medium-size industrial
enterprises to provide local construction materials of all types to keep the cost of producing
houses within reasonable limits. Primary Mortgage Institutions are to be mobilized to assist
any Nigerian desirous of purchasing a house to access mortgage finance and the restructuring
of the Federal Mortgage Bank of Nigeria to be able to provide ample and abundant funds
besides the National Housing Trust Fund to meet the secondary mortgage transactions for
home-ownership; the reviewing and amendment of all legislations necessary to facilitate the
robust development of home-ownership in the country. To also set up a Federal Ministry of
Housing and Urban Development to regulate, promote, monitor and supervise all of these
changes."

(Mabogunje, 2004, P.1)

Thus apart from radical legislative reforms on land, the foreclosure procedure was to be made faster to enhance the operation of the new mortgage-based housing finance system. More importantly, the organized private sector housing developers was made the fulcrum of housing delivery in the country. This led to the facilitation of the formation of the Real Estate Developers Association of Nigeria (REDAN), made up of private real estate developers and state housing corporations that are accessing loans on concessionary interest rates to supply housing to Nigerians. Similarly, government facilitated the formulation of the Building Materials Producers Association of Nigeria (BUMPAN), who also access loans at concessionary interest rates to produce building materials at affordable prices to tackle high cost of mostly imported building materials relied upon by the building industry in the country. It is believed that all these will make prices of houses delivered by the organized private sector reasonable and affordable. Furthermore, recent efforts include the recapitalization of Federal Mortgage Bank of Nigeria with Five Hundred Billion Naira $(\$ 500,000,000,000.00)$ to enhance access to mortgage loan. Additionally, Federal Government built up the Nigeria Mortgage Refinancing Company (NMRC) to connect the financing cost of private home loans and advance the accessibility just as the affordability of good housing to Nigerians by giving expanded liquidity in the mortgage loan advertise through the mortgage loan and commercial banks. NMRC commenced with the World Bank concessional credit of US\$300million to have the option to play out the appointed role in the Nigeria housing finance framework. The introduction of Collateral Replacement Indemnity (CRI), waiver of 10\% down payment for mortgage loans less than Five Million Naira $(\$ 5,000,000.00)$ and Loss of Job Insurance as well as the amendment of National Housing Fund by National Housing Fund Establishment Act 2018. The introduction of One Trillion Naira $(\$ 1,000,000,000,000.00)$ Social Housing Fund, with a yearly contribution of One Hundred Billion Naira ( $\$ 1,000,000,000.00)$ by the Federal Government to provide inexpensive mortgages to Nigerians, were all meant to boost inclusion and enhance mortgage penetration among Nigerians, particularly those hitherto undeserved. Finally, the Federal Government introduced the Federal Integrated Staff Housing Programme (FISH-P) to provide sustainable housing to low and medium income earners (Federal/Public Servants) who cannot afford the prevailing market prices. The cursory look at the housing policies and delivery has revealed the extreme bias in favour of home ownership with less consideration for renting as a tenure option. This was confirmed by Olufemi (1997) when he asserted that "Increasing the level of home ownership has been the cardinal goal of the Nigerian housing policy." Despite the favourable disposition of succeeding governments and housing policies to home ownership in Nigeria, the number of tenants continues to grow, particularly in our urban centres; with the climax in Lagos, where today almost $76 \%$ of households are tenants. 


\section{Housing Tenure Choice and Housing Affordability: The Nexus}

The neo-classical Theory of Consumer Choice provided a nexus for housing affordability and housing tenure choice. This theory offered a good theoretical anchor for the analysis of the relationship between housing tenure choice decision and housing affordability and how they affect each other.

The theory of consumer choice, according to Mankiw (2015) explains the trade-offs that people face in their role as consumers. This is anchored on the first of Ten Principles of Economics; which states that "people face trade-offs among alternative goals, that the cost of any action is measured in terms of forgone opportunities (alternative forgone), that rational people make decisions by comparing marginal costs and marginal benefits." To illustrate this theory, it is assumed that there are only two items in the consumption basket. That means in taken decision, a household must decide on the best combination to choose; within their income and prices of the items. Here, a consumers budget constraint shows the possible combination of different goods that they can afford to buy given the income and the prices of the goods. Therefore, a household can choose to buy one of the two (2) items or combine them in a preferred proportion. The more of one consumed, the less of the other can be consumed. The preferences of the household represent their indifference curves. Different possible combinations of these two (2) items will therefore produce different indifference curves. So, if the household chooses to spend all their income on one of the items, they will have to forgo the other totally, in which case, the one they forgo can be regarded as the real cost of the chosen one.

In the case of housing affordability the two goods to choose from are housing and other non-housing necessities, which must be combined in a reasonable proportion in order not to jeopardize the health of the household. In the case of choosing between owning and renting, a household can only choose either of the two. Interestingly, that is the nexus between the housing affordability and the tenure choice decision. Therefore, the household will have to make the tenure choice decision first, and whatever decision is made will affect housing affordability of the household, because it is the residual that is left that will be available for other non-housing necessities. This therefore takes us to the Housing and Other Goods Theory and its relevance to both housing affordability and housing tenure choice decision. This theory is an adaptation and application of the neo-classical theory of consumer choice to explain housing tenure choice decision and how it affects housing affordability of a household. Once a household chooses either owing or renting, it will determine how much the household will spend on housing and how much is left (Residual) for other non-housing necessities and hence housing affordability. According to Jameson et al (2004), the neo-classical theory of consumer choice is therefore helpful so far as it potentially identifies the inter-related set of influences that impact at the high level choice between housing and other goods. It also provides the rationale for pursuing investigation of the rental versus ownership options."

\section{Research Setting and Methodology}

\subsection{Research Setting}

This research was based on data collected from eleven (11) states and the Federal Capital Territory, in the six (6) geo-political zones of Nigeria. The 2002 National Housing Policy introduces a major shift in the housing delivery in Nigeria from public delivery to public sector facilitated private sector housing delivery. However, the emphasis was still on homeownership without any formal recognition of rental housing market, despite its growing importance in the housing of urban dwellers in Nigeria. The emergence and growing importance of organized private sector Real Estate Developers Association of Nigeria (REDAN) in housing delivery lead to the development of housing estates in all parts of the six (6) geo-political zones of the country, but mostly in urban areas. The selection was based on two (2) states with the prevalence of organized private sector housing estates. The selected states in each of the six (6) geo-political zones are: South-West: Lagos and Ogun; South-South: Edo and Rivers; South-East: Enugu and Abia; North-Central: Federal Capital Territory and Nassarawa; North-West: Kaduna and Katsina; and North-East: Bauchi and Gombe.

\subsection{Research Methodology}

A cross-sectional survey design was adopted while multi-stage sampling technique was used to choose residents of the sampled estates for interview. Structured questionnaires were administered on $10 \%(1,950)$ heads of households that were randomly selected from the occupied houses $(19,500)$ in the selected estates. A simple random sample is a subset of a statistical population in which each member of the subset has an equal probability of being chosen (Creswell, 2017). The structural questionnaire was used to elicit information on household's social, economic, and demographic attributes such as household size, income, status in the house (owner or renter), and housing expenditure, among others. The information collected was analyzed to determine the proportion of household income being expended on housing and thereafter establish the residual that is available for other non-housing necessities. The tenure status was equally analyzed and the degree of incursion of housing expenditure into what is available for all other non-housing necessities required for a healthy living was compared for owners' and renters' households. 


\section{Data Analysis and Result}

The beneficiaries of organized private sector housing were first separated into owners and renters. Thereafter, their housing affordability were analyzed relying on the residual income approach, anchored on the housing and other goods theory. Thus, we assumed that there are only two items in the consumption basket of a household - housing and all other goods of necessities; to which household expend their income. Since housing affordability measure the degree of incursion of housing expenditure into what is available for other non-housing necessities, the housing affordability of owners and tenants were then compared. The analysis of tenure status revealed that about $48 \%$ are owners; while about $52 \%$ are tenants. Further analysis revealed that among the owners $7 \%, 10 \%$ and $12 \%$ spent $1-10 \%, 10.1-20 \%$ and $20.1-30 \%$ of their income on housing respectively. Those that spent between $30.1 \%$ and $50 \%$ on housing constitute $15 \%$ and $21 \%$ respectively. The other $35 \%$ spent between $50.1 \%$ and $80 \%$ of their income on housing which is made up of $28 \%, 5 \%$ and $2 \%$ that spent $50.1 \%-60 \% ; 60.1 \%-70 \%$ and $70.1 \%-80 \%$ on housing respectively. For the renters, further analysis revealed that about $8 \%, 18 \%$ and $15 \%$ spent $1-10 \%, 10.1-20 \%$ and $20.1 \%-30 \%$ of the households income on housing respectively. Those that spent $30.1 \%-40 \%$ and $40.1 \%-50 \%$ constitute $23 \%$ and $18 \%$ respectively. The remaining $18 \%$ spent between $50.1 \%-60 \%$ and $60.1 \%-70 \%$ of the household's income on housing at $13 \%$ and $5 \%$ respectively. The comparative housing affordability graph of owners and renters is depicted in figure 5.1 below. The implication of this finding is that while only $28 \%$ of owners are within "normal housing affordability" $41 \%$ of renters enjoyed the same. Similarly, while $37 \%$ of owners fall within "tolerable housing affordability," $41 \%$ of renters are within that zone. Finally, while about $35 \%$ of owners are under "housing affordability stress," only $18 \%$ of tenants are under housing affordability stress. Therefore, we can infer from the findings that comparatively, renters enjoy better housing affordability than the owners.

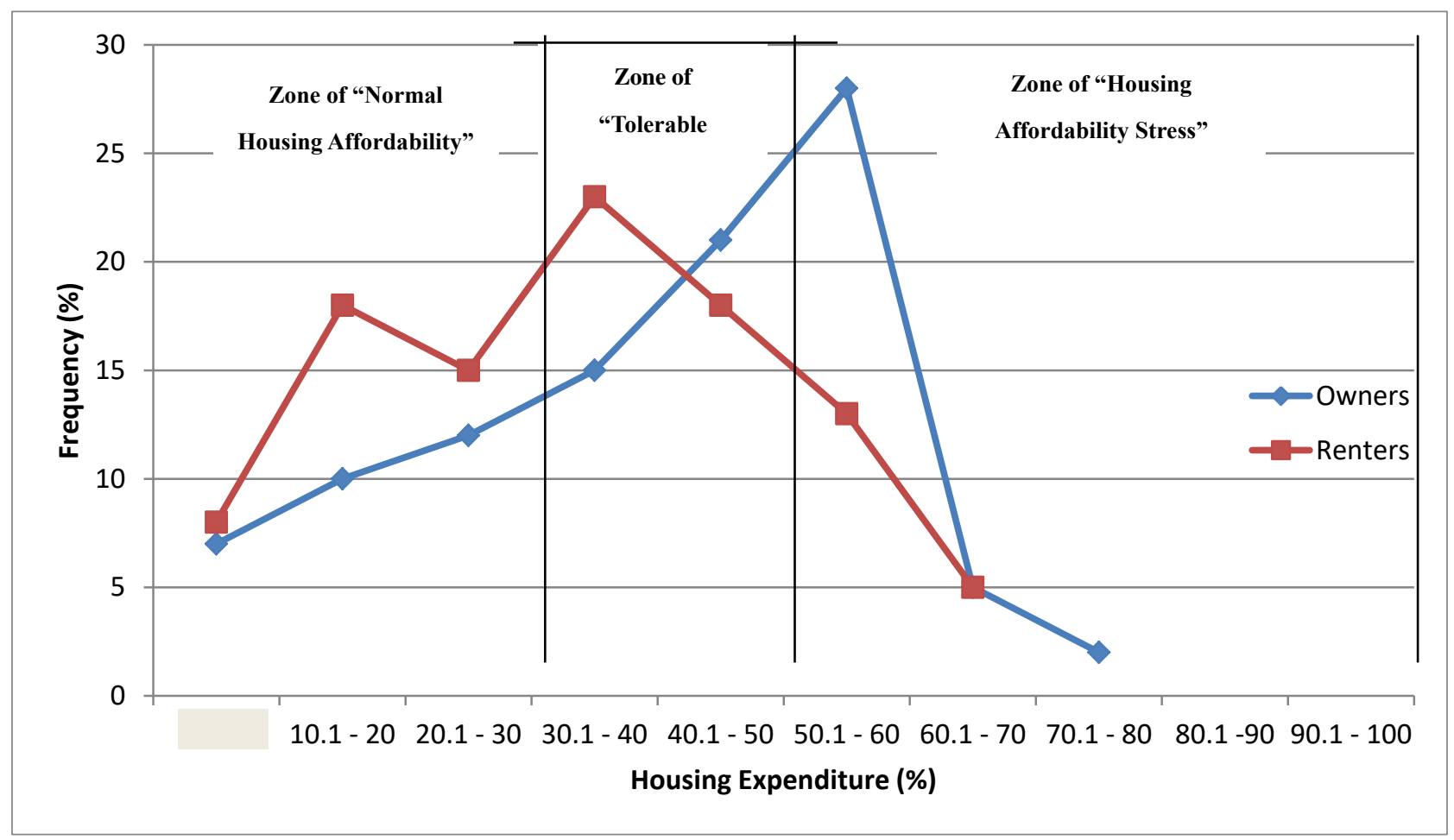

Figure 5.1. Comparative Housing Affordability of Owners and Renters of Organized Private Sector Housing

\section{Findings, Policy Implications and Conclusion}

\subsection{Findings and Policy Implications}

The major finding from this research is that more owners are under severe housing affordability stress/burden when compared to the renters. Also, this research revealed that generally, the renters enjoyed better housing affordability. This study therefore confirmed that ownership option worsened housing affordability of most owners in Nigeria. This is why some households can hardly meet most of their needs for other non-housing necessities after meeting their housing expenditure which may eventually lead to what Kutty (2005) properly described as "housing induced poverty" and which Stone (2006) called housing poverty. This is reflected in this study where $29 \%$ of owners fall within normal housing 
affordability (spending 1\% - 30\% of income on housing), $41 \%$ of renters are within the zone. Furthermore, while $41 \%$ of renters fall within tolerable housing affordability zone, (spending $30.1 \%-50 \%$ of income on housing) only $36 \%$ of owners are within that zone. Similarly, while $35 \%$ of the owners are theoretically under severe housing affordability stress/burden (those spending above $50 \%$ of their income on housing), only $18 \%$ of renters are having similar experience. Interestingly, the findings from this study are a departure from the findings from most developed countries, where renters experienced severe housing affordability more than owners. For instance, Giaccaria et al (2008), confirmed a strong trend to the homeownership for the families of renters and that high level of rent is systematically associated with a reduced chance of changing for the medium-income households. Furthermore, Moore and Skaburskis (2004) in a study in Canada concluded that tenure is a fundamental differentiator of the incidence of high expenditure-to-income ratios, as renters have the highest percentage of households paying more than $30 \%$ and more than $50 \%$ of income on shelter. In opposition to the discoveries from the developed world, it is anyway obvious from this study that while numerous owners are under substantial burden of housing affordability (Spending over half of their pay on housing), less tenants are under comparable condition. The contrast between our discoveries and those from developed world might be because of different assistance given to the property owners and presence of well-developed mortgage system in the developed countries.

The most significant policy implication of the finding is that the objective of access to housing at affordable rate might be better accomplished if rental housing is perceived as a housing solution in government housing policy and delivery. Besides, more individuals can be brought out of housing affordability stress/burden if government housing delivery policy gives priority attention to rental housing as given to ownership. This is particularly important in our urban areas where the number of renters is increasing rapidly. On the other hand, government should review the conditions for home ownership such as mortgage terms, particularly, down payment, interest rates and repayment period; so as to relief the burden of home ownership. Finally, efforts should be made to ease the burden of home ownership by critically working on cost of building materials, property taxation and all other incidental expenses of ownership so as to make housing affordability profiles of owners more favourable.

\subsection{Conclusion}

In the course of a lifetime, individuals exercise tenure choice decision. One of the key decisions made by any household is choice between owning and renting their home (Dagmar et al, 1997). Arimah (1997) confirmed that a key factor in tenure choice decision is the relative price of home-owning to that of renting. The findings from this study revealed that tenure choice decision have serious implications on other decisions of the household and hence their general wellbeing. Thus, housing tenure choice decision that may appear as a simple binary choice between renting and owning might as well reflect a tighter constraints on other items in the consumption basket of the household; (Jameson and Nana, 2004) with serious implications for the overall welfare of the household. This study has established the effect of housing tenure choice decision on housing affordability in Nigeria. Therefore, housing tenure choice decision must always be taken as an integral part of an overall decision of a household rather than an isolated independent decision. Furthermore, since housing tenure choice decision infringes on housing affordability, government should de-emphasis ownership in their housing policy and delivery and recognize rental tenure as an option in enhancing access to housing in the country. Also, efforts should be made to ease the burden of home ownership by critically working on cost of building materials, access to land, mortgage terms, and property related taxes. All these will go a long way to reduce the negative impact of housing tenure choice decision on housing affordability and thus enhance the housing affordability profiles of Nigerians.

\section{References}

Adegoke, S. A. O. (2016). Housing affordability in Nigeria: A study of the organized private sector housing. Unpublished PhD Thesis, Ibadan: Department of Urban and Regional Planning, Faculty of the Social Sciences, University of Ibadan.

Adegoke, S. A. O., \& Agbola, T. (2020). Housing affordability and the organized private sector housing in Nigeria. Open Journal of Social Sciences, 8, 177-192. https://doi.org/10.4236/jss.2020.84013

Agbola, S. B. (2005). The housing debacle; An inaugural lecture delivered at the university of Ibadan. Ibadan, Nigeria. pp. 14

Agbola, T., Egunjobi, L., \& Olatubara, C. O. (2016). Housing development and management (2nd ed.). Department of Urban and Regional Planning. University of Ibadan, Ibadan, Nigeria. pp. 1-24

Arimah, B. (1997). The determinants of housing tenure choice in Ibadan. Urban Studies, 34(1), 105-124. https://doi.org/10.1080/0042098976294

Bunting, T., Walks, R. A., \& Fillion, P. (2004). The uneven geography of housing affordability stress in Canadian Metropolitan Area. Housing Studies, 19(3), 361-393. https://doi.org/10.1080/0267303042000204287 
Creswell, J. W. (2017). Qualitative Inquiry and Research Design: Choosing among Five Approaches (3rd ed.). Washington DC: Sage.

Dagmar, S., \& Spalek, J. (2014). Housing tenure choice and housing expenditure in the Czech Republic. Review of European Studies, 6(1), 1-25. https://doi.org/10.5539/res.v6n1p23

FGN (1975). Third national development plan 1975 - 1980. Federal Ministry of National Planning. Lagos, Nigeria.

FGN (1979). Constitution of Federal republic of Nigeria. The Federal Military Government, Lagos.

FGN (1991). National housing policy for Nigeria. Federal Ministry of Works and Housing.

FGN (2004). Guide for the 4th National Policy, Federal Ministry of Housing and Urban Development, Abuja. pp. 18.

James, B., \& Nana, G. (2004). Furthering our understanding of tenure transition. The Impact of Financial Circumstances on Tenure Choice in NZ. Business and Economic Research Limited. pp.10-28.

Kutty, N. K. (2005). A new measure of housing affordability: estimates and analytical results. Housing Policy Debate, 16(1), 113-142. https://doi.org/10.1080/10511482.2005.9521536

Mabogunje. (2004). 2002. National housing and urban development policy: Catalyst for mass housing delivery in Nigeria." Paper delivered at the $2^{\text {nd }}$ Abuja International Housing Summit, Le Maridian Hotel, Abuja, $27^{\text {th }}-29^{\text {th }}$ April, Organized by House of Representative Committee on Housing and Urban Development. Pp.1-20

Mankiw, N. G. (2015). Principles of microeconomics, $7^{\text {th }}$ edition engage learning. Stamford, USA.

Moore, E., \& skaburskis, A. (2004). Canada's increasing housing affordability burdens. Housing Studies, 19(3), 395-412. https://doi.org/10.1080/0267303042000204296

Olufemi, A. O. (1997). Rental housing market in Ibadan. NISER Monograph Series No.6. NISER, Ibadan. pp. 45-56.

Onibokun, A. G. (1985). Housing in Nigeria. Nigeria Institute for Social and Economic Research. Ibadan. pp. 55

Oyo-Ita, W. E. (2017). Tackling the housing affordability challenge: Nigeria experience. Paper Presented at the $30^{\text {th }}$ International Union of Housing Finance (IUHF) World Congress on "Global Opportunies in Housing Finance." Washington DC, USA.

Stone, M. E. (2005). A housing affordability standard for the UK. Housing Studies, 21(4), 1-18. https://doi.org/10.1080/02673030600708886

Stone, M. E. (2006). What is housing affordability? The case for residual income approach. Housing. Policy Debate, 17(1), 151-184. https://doi.org/10.1080/10511482.2006.9521564

Turner, M. A., \& O’Neal, K. (1986). Household tenure choice: Review of the empirical literature. Office of Policy Development and Research. Department of Housing and Urban Development. pp. 95-120.

World Bank. (1993). Housing: enabling markets to work. The International Bank for Reconstruction and Development / The World Bank. Washington DC. pp. 45.

Yang, Z., \& Shen, Y. (2008). The affordability of owner occupied housing in Beijing. J. Housing and Built Environ, 23, 317-335. https://doi.org/10.1007/s10901-008-9120-2

\section{Copyrights}

Copyright for this article is retained by the author(s), with first publication rights granted to the journal.

This is an open-access article distributed under the terms and conditions of the Creative Commons Attribution license which permits unrestricted use, distribution, and reproduction in any medium, provided the original work is properly cited. 